\title{
HORMONE-MIMICKING CHEMICALS What They Are, What They Do, and Where to Find Them
}

RARELY DO WE CONSIDER WHAT THE CHEMICALS THAT GO INTO OUR CONSUMER PRODUCTS, THAT ARE SPRAYED ONTO OUR FRUITS, OR THAT ARE RELEASED INTO THE AIR ACTUALLY DO. FOR EXAMPLE, WE ASSUME THAT THOSE DIFFICULT-TO-READ CHEMICALS ON OUR SHAMPOO BOTTLE LABELS ARE SAFE. HOWEVER, FEW OF THE THOUSANDS OF CHEMICALS DEVELOPED EACH YEAR ARE THOROUGHLY TESTED. FORGOING THE PRECAUTIONARY PRINCIPLE, WE ARE EXPOSED TO MANY CHEMICALS THAT ACT AS ENDOCRINE DISRUPTORS. ENDOCRINE DISRUPTING CHEMICALS (EDCS) CAN MIMIC, BLOCK, OR RE-ROUTE THE HORMONAL SIGNALING OF OUR BODIES. THIS ARTICLE ADDRESSES WHATEDCS ARE, HOW THEY ACT, AND HOW THEY CAUSE HARMFUL EFFECTS, SUCH AS REPRODUCTIVE ABNORMALITIES, CANCERS, ANDBEHAVIORAL CHANGES. FINALLY, STEPS THAT WE AS CONSUMERS CAN TAKE TO AVOID OR NEGATE THOSE EFFECTS ARE ENUMERATED. 


\section{INTRODUCTION}

In the twenty-first century, the use of synthetic chemicals is an afterthought. 'Though not always desired, they are thoroughly integrated into daily life. Embedded into everything we touch, smell, eat, and breathe, the prevalence of these chemicals makes it difficult to stop, take a step back, and assess the long-term effects. The demand for immediate convenient improvements, the encouragement of technological advancements in agriculture, manufacture, and medicine, and the difficulty of moving beyond the cancer paradigm mean that very few of the thousands of chemicals developed every year are tested for effects beyond toxicity. Therefore, many of the chemicals that go into our products, like water bottles, perfumes, shampoos, and plastic toys may act as endocrine disruptors, which mimic, block, or reroute the hormonal signals of our bodies. Previous studies in rodent and fish model organisms and human cell lines have shown that chemicals such as bisphenol A and phthalates, which act as estrogens and antiandrogens respectively, increase occurrences of cervical and prostate cancer, advance puberty, feminize males, increase reproductive organ malformations, and affect the integrity of DNA. Together these studies provide the basis for a theory that the drastic decline in human sperm count in the last fifty years and the increasing number of reproductive organ abnormalities, cancers, and allergies results, in part, from the use of these chemicals that affect hormonal signaling pathways.

\section{ENDOCRINE DISRUPTORS: CHARACTERIS-}

\section{TICS AND MECHANISM OF ACTION}

Endocrine disrupting chemicals (EDCs) interfere with normal signaling of the body's intricate hormonal networks. Hormones, biochemical messengers controlling much of the body's functions, act as the intermediaries between signals and actions. One part of the body, such as the pituitary gland, sends a message, like luteinizing hormone, to illicit an action in another part of the body, like stimulating an ovary to release an egg. Examples of hormones range from growth hormones, which control development, to thyroxine, which helps manage metabolism, to insulin, which regulates blood glucose levels, to the sex hormones that rule sexual development and reproduction. The body's delicate hormonal balance necessitates signal consistency. The great complexity encompassed in only the endocrine system is delicate and sensitive in and of itself, without external influences such as EDCs.

The hormonal pathway is complex at the cellular level. After traveling through the blood, a hormone must interact with a target cell. If the hormone is a steroid, and therefore fat soluble, it can cross the cell membrane. Inside, it binds with its complement receptor, which then binds to DNA within the nucleus. Consequently, target genes are expressed, leading to proteins that accomplish the action specified and initiated by the original signal. Examples of these effects include stimulation or inhibition of growth, induction or suppression of cell death, activation or inhibition of the immune system, regulation of metabolism, preparation for physical activity, preparation for puberty, and control of the reproductive cycle. Endocrine disruptors mimic endogenous hormones by binding to the normal receptors and subsequently triggering an action even when the actual hormone is not present. Endocrine disruptors can also block essential signaling by interfering with the receptor, intermediate molecules, enzymes, or transport proteins. ${ }^{i}$ It is also possible for EDCs to alter the action altogether by, in effect, giving the body "new" or distorted instructions. ${ }^{\text {ii }}$

Fat-insoluble hormones and EDCs trigger actions inside the cell by binding externally to receptors on the cell membrane. Through a series of conformational changes, the receptor initiates signal transduction, a type of relay between multiple molecules within the cell. The signaling molecule thus elicits an action that is not only amplified thousands of times compared to the original signal, but also occurs in much less time than it takes for genes to be expressed.

\section{ENDOCRINE DISRUPTORS ACT UNDER}

THE RADAR

Chemical testing methods have traditionally focused on as- 
sessing acute toxicity, reflected by mortality or poisoning of test animals. Based on the assumption that "the dose makes the poison," chemical testing is still focused on toxicity at relatively high concentrations. Graphing toxicity test results is expected to produce a linear dose response curve, with higher response corresponding to increased dosage. Chemicals approved for use in consumer products, of course, show a negligible toxic effect at high concentrations, leading scientists to presume that these chemicals are not harmful at any concentration. To the contrary, the newly recognized class of EDCs has profound deleterious effects at doses hundreds, or even thousands, of times lower than supposedly "safe" concentrations determined by classic toxicity testing. As EDCs can interrupt hormonal pathways at tiny doses of parts per million, or even parts per billion, daily exposure to seemingly inconsequential amounts of EDCs can lead to drastic effects.

Many EDCs actually elicit a "U-shaped" dose response curve. In other words, some EDCs at very low and very high concentrations may not show as strong an effect as exposures to EDCs at concentrations somewhere in the middle, or conversely, the middle doses may not have as great an effect as low and high doses. Assessment of the hazards of EDCs is also complicated by the fact that their effects are not as acute as outright poisoning and are usually not observed immediately after exposure. iii Therefore, fetal exposure may not result in any apparent consequences until later in adulthood, with onset of infertility problems, cancers, and behavioral abnormalities.

\section{BISPHENOL A}

Bisphenol A (BPA) is an EDC that acts as an estrogen mimic. In 2004, the United States alone produced about one million tons. As an ingredient in polycarbonate plastics, BPA gives the characteristic of durability. Thus, polycarbonate is used to make baby bottles, water bottles, toys, and medical devices. BPA can also be found in the epoxy resins that coat the inside of food and beverage cans and in dental sealants. ${ }^{\text {iv }}$ In humans, BPA has been measured in amniotic fluid, maternal and fetal plasma, and placental tissue at birth.

Due to the numerous ways that BPA infiltrates daily life, there are significant concerns that exposure to BPA at the levels found in adults, and especially in the developing fetus (which has an under-developed ability to remove BPA), has long-term adverse health consequences. These concerns are based on hundreds of studies using animal model and tissue culture systems that demonstrate effects of BPA at levels equivalent to, and even lower than, the levels detected in human blood and urine (Table I).

A study using BPA doses below what the EPA's safety guidelines found that BPA (in conjunction with insulin) triggers the formation of fat cells in mice. After eleven days, with BPA exposure in only the first two days, fat content in the cells increased by 150 percent compared to controls. When the cells were exposed to BPA for II full days, there was a I,300 percent increase in fat content. ${ }^{v i}$ Similar findings from other research groups, coupled with measurable levels of BPA and a host of other EDCs in humans, have raised concerns of a causal link between bodily EDC levels, also known as body burden, and the current obesity epidemic. ${ }^{\text {vii }}$

\section{DID YOU KNOW?}

\section{Contaminants and viruses can work together.}

ELEVATED LEVELS OF PSBS AND EPSTEIN BARR VIRUS INCREASE THE RISK OF NON-HODGKIN'S LYMPHOMA BY OVER 20-FOLD. viii 


\section{DAILY BPA EXPOSURE}

(MCC/KC BODYWEICHT-DAY)... TOXIC EFFECT

STUDY DETAILS

REFERENCE

\section{PERSISTENT CHANG ES TO BREAST TISSUE,}

0.025

2.4

2.5

10

10

20

30

30

50
PERMANENT CHANGES TO GENITAL TRACT

INCREASED ACG RESSION AT 8 WEEKS OF LIFE

DECLINE IN TESTICULAR TESTOSTERONE

IMMUNE SYSTEM IMPACTS

PROSTATE CELLS MORE SENSITIVE TO HORMONES AND CANCER INSULIN RESISTANCE DEVELOPS IN 2 DAYS, CHRONIC HYPERINSULINEMIA AT DAY 4

DAMACE TO EGGS AND CHROMOSOMES

REVERSED THE NORMAL SEX DIFFERENCES IN BRAIN STRUCTURE AND BEHAVIOR

HYPERACTIVITY

EPA RFD (REFERENCE DOSE)
FETAL EXPOSURE, CHANG ES NOTED AT 6 MONTHS OF AGE

FETAL EXPOSURE

FETAL EXPOSURE, ORAL ROUTE

FETAL AND NEONATAL EXPOSURE, CAVAGE

ORAL EXPOSURE

FETAL EXPOSURE, ORAL ROUTE, SHORT DURATION

SUBCUTANEOUS INJECTION, SHORT DURATION EXPOSURE

FETAL EXPOSURE, OSMOTIC PUMPS

oral during gestation and lactation

ORAL

EPA'S "SAFE EXPOSURE LEVEL," BASED ON OUTDATED, hIGH DOSE STUdies ANDA 1000-FOLD MARGIN OF SAFETY
MUNOZ-DE-TORO 2005

MARKEY 2005

KAWAI 2003

ARKINGBEMI 2004

SAWAI 2003

TIMMS 2005

ALONSO-MAGDALENA 2006

HUNT 2003

KUBO 2001

SSHIDO 2004

EPA 1998

\begin{tabular}{|c|c|c|c|c|c|c|c|}
\hline \multicolumn{8}{|c|}{ ENDOCRINE } \\
\hline RECEPTOR & USED AS & FOUND IN & ACTS AS & LINKED TO & TITLE & DESCRIPTION & WEBSITE \\
\hline BISPHENOLA & $\begin{array}{l}\text { EPOXY RESINS OF } \\
\text { CANS, POLYCARBON- } \\
\text { ATE PLASTICS, DENTAL } \\
\text { SEALANTS }\end{array}$ & $\begin{array}{l}\text { HARD PLASTIC WATER } \\
\text { BOTTLES, PLASTIC } \\
\text { TOYS }\end{array}$ & ESTROCEN & $\begin{array}{l}\text { CANCER/TREATMENT } \\
\text { RESISTANCE, FEMI- } \\
\text { NIZATION/MASCULIN- } \\
\text { ZATION, DNA } \\
\text { INTEGRITY }\end{array}$ & $\begin{array}{l}\text { THE CAM PAIGN FOR SAFE } \\
\text { COSMETICS }\end{array}$ & $\begin{array}{l}\text { AIMS "TO PROTECT THE HEALTH OF } \\
\text { CONSUMERS AND WORKERS BY REQUIR- } \\
\text { INC THE PERSONAL CARE PRODUCTS } \\
\text { IN DUSTRY TO PHASE OUT THE USE OF } \\
\text { CHEMICALS LIN KED TO CANCER, BIRTH } \\
\text { DEFECTS AND OTHER SERIOUS HEALTH } \\
\text { CONCERNS, AND TO REPLACE THEM } \\
\text { WITH SAFER ALTERNATIVES." }\end{array}$ & WWW.SAFECOSMETICS.ORC \\
\hline PHTHALATES & $\begin{array}{l}\text { PLASTICIZER, } \\
\text { FRAGRANCES }\end{array}$ & $\begin{array}{l}\text { NAIL POLISH, PER- } \\
\text { FUMES, PLASTIC } \\
\text { SHOWER CURTAINS }\end{array}$ & ANTI-ANDROGEN & $\begin{array}{l}\text { MALE GENITAL } \\
\text { ABNORMALITIES, } \\
\text { MALE INFERTILITY } \\
\text { (LOW SPERM COUNT) }\end{array}$ & SKIN DEEP & $\begin{array}{l}\text { "A SAFETY GUIDE TO COSMETICS AND } \\
\text { PERSONAL CARE PRODUCTS BROUGHT } \\
\text { TO YOU BY RESEARCHERS AT THE ENVI- } \\
\text { RONMENTAL WORKING GROUP." }\end{array}$ & WWW.COSMETICSDATABASE.COM \\
\hline PARABENS & $\begin{array}{l}\text { PRESERVATIVE IN COS- } \\
\text { METICS \& PHARMA- } \\
\text { CEUTICALS }\end{array}$ & $\begin{array}{l}\text { MOISTURIZERS, } \\
\text { SHAMPOOS }\end{array}$ & ESTROCEN & $\begin{array}{l}\text { BREATS CANCER, RE- } \\
\text { PRODUCTION ABNOR- } \\
\text { MALITIES/INFERTILITY }\end{array}$ & $\begin{array}{l}\text { WOMEN'S HEALTH AND THE } \\
\text { ENVIRONMENT }\end{array}$ & $\begin{array}{l}\text { A WEBSITE THAT "EXPLAINS WAYS THAT } \\
\text { OUR HEALTH CAN BE AFFECTED BY ENVI- } \\
\text { RONMENTAL CONTAMINANTS AND OF- } \\
\text { FERS IDEAS OF HOW TO MAKE CHANGES } \\
\text { AROUND YOUR HOME AND IN YOUR } \\
\text { COMMUNITY SO WE CAN LIVE INA } \\
\text { HEALTHIER WORLD." }\end{array}$ & $\begin{array}{l}\text { WWW. WOMENSHEALTHANDEN- } \\
\text { VIRONMENT.ORC }\end{array}$ \\
\hline LEAD & PIGMENT & $\begin{array}{l}\text { LIPSTICK, DARK HAIR } \\
\text { DYES }\end{array}$ & NEUROTOXIN & $\begin{array}{l}\text { COCNITIVE REDUC- } \\
\text { TION, DELAYED PU- } \\
\text { BERTY }\end{array}$ & $\begin{array}{l}\text { CREEN GUIDE FOR EVERYDAY } \\
\text { LIVING }\end{array}$ & $\begin{array}{l}\text { PROVIDED BY NATIONAL GEOCRAPHIC, } \\
\text { INFORMATION COVERING A RANGE } \\
\text { FROM CARPETS TO CLEANING PROD- } \\
\text { UCTS TO SUNSCREEN. }\end{array}$ & $\begin{array}{l}\text { WWWW.THECREENGUIDE.COM/BU } \\
\text { YING-GUIDE }\end{array}$ \\
\hline
\end{tabular}


In a related study, scientists found a correlation between high urinary BPA concentrations and both cardiovascular disease and diabetes in humans. ${ }^{\text {ix }}$ In addition, mice exposed to BPA through damaged polycarbonate cages and water bottles (by normal wear and tear) led to meiotic aneuploidy, or an incorrect number of chromosomes present in the cells that develop into eggs. These observations and similar studies indicate that human exposure to BPA may incite numerical chromosomal abnormalities, the leading causes of miscarriage, congenital defects, and mental retardation. ${ }^{\mathrm{x}}$

BPA exposure has been linked to cancers, including breast and prostate cancer. Pregnant rats treated with $25 \mathrm{mcg} / \mathrm{kg}$ body weight per day gave birth to daughters that showed permanently altered mammary glands with cell proliferation and an increase in susceptibility to a tested carcinogen. ${ }^{x i}$ In effect, cells became sensitized by BPA to respond to a carcinogen even before birth. In the United States, prostate cancer is the second leading cause of cancer death among men and the leading diagnosed malignancy.xi Prostate cancer depends on testosterone for growth, so treatments focus on testosterone deprivation either through inhibition of testosterone synthesis or by blockage of the testosterone receptor. This type of treatment is successful for up to 18 to 30 months when recurrent tumors develop in some patients. xiii Growth of recurrent tumors can be stimulated by a variety of mechanisms. In one study, 25 percent of the recurrent tumors had acquired a mutation in the testosterone receptor that changed the shape of the testosterone-binding site. Therefore, although the ablation therapy had removed all testosterone from the patients bodies, the tumors were sensitive to stimulation by other compounds, including estrogen and BPA.xiv Essentially, BPA can bind to the mutated receptor and stimulate cell growth and proliferation, events normally stimulated by testosterone, thus advancing the prostate cancer.

BPA exposure also interferes with sex specific development of the body and brain. BPA in only parts per billion has been shown to masculinize areas of the female brain. The development of the area of the brain responsible for estrous cyclicity, gonadotropin release, and the luteinizing hormone surge necessary for ovulation is different in male and female rats. However, in pregnant rats exposed to BPA, the daughters' brains began to resemble those of males, and the daughters exhibited masculinized behavior. This study shows that BPA can cross the placental barrier and that the fetus is extremely sensitive to exposure, leading to longerlasting effects. ${ }^{\mathrm{xv}}$

Additionally, pregnant rats exposed to BPA had daughters with accelerated puberty. In fact, endocrine-disrupting chemicals may be one of the causes of the global trend of earlier sexual maturation in girls. ${ }^{x i}$ In the United States, girls begin menstruation a few months earlier than they did 40 years ago and develop breasts I-2 years earlier. ${ }^{\text {xvii }}$ Puberty at a younger age has been linked to an increased risk for depression, obesity, polycystic ovarian syndrome, breast cancer, and ovarian cancer. ${ }^{x v i i i}$ Social problems such as an increased risk of sexual victimization and experimentation with sex, alcohol, or drugs may become more likely at an earlier age. ${ }^{\text {ix }}$ Earlier puberty may also lead to addi-

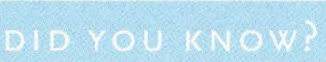

\section{EDCs can increase immune responses and allergic reactions.xx}

SINCE 1980 ASTHMA DEATH RATES FOR CHILDREN YOUNGER THAN 19 YEARS OLD HAVE INCREASED BY ALMOST $80 \%$. xxi

THE PREVALENCE OF PEANUT ALLERGIES DOUBLED IN THE 5 YEARS FROM 1997

TO 2002.xxii

CHILDREN WITH ELEVATED LEVELS OF CONTAMINANTS ARE 8X MORE LIKELY TO HAVE CHICKEN POX AND 3X MORE LIKELY TO HAVE 6 OR MORE EAR INFECTIONS BY THE ACE OF $31 / 2$. xxiii 
tional physical and behavioral problems later in life due to longer exposure to hormones.

BPA can interact with both cell membrane and internal cellular receptors. For example, BPA interacts with cell membrane receptors and increases prolactin secretion from cells. Increased prolactin can lead to a decrease in fertility, cell proliferation, behavioral effects, and interference with ovulation. xxiv BPA also interacts with both types of pancreatic cell receptors. In effect, these cells rapidly release insulin into the bloodstream to decrease glucose levels. With longer exposures to BPA, the cells secrete too much insulin, which eventually leads to insulin resistance. In other words, target cells no longer uptake glucose in response to insulin because the signal is constant and the cell is no longer sensitive to it. Therefore, exposure to environmental estrogens can enhance the risk of developing type 2 diabetes, hypertension, and abnormal levels of fats in the blood. xxv

\section{OTHER EDCS}

Other chemicals act by mimicking or blocking testosterone. Some, like vinclozolin (a fungicide), demasculinize male rats, exemplified by a decreased anogenital distance (AGD), retained nipples, hypospadias, and absent sex accessory glands.xxvi

Phthalates are another class of testosterone-blocking chemicals used as plasticizers in products such as food containers, toys, medical equipment, and shower curtains. Perfumes, hairspray, cosmetics, and the new car smell can also contain phthalates. The term "phthalate syndrome" has been coined to describe genital abnormalities that are a result of exposure to phthalates, including undescended testicles. A human study conducted by the Centers for Disease Control, Harvard School of Public Health, the Dana Farber Cancer Institute, and Harvard Medical School examined the correlation between phthalate levels in urine samples and various sperm parameters in 168 men. Semen samples were analyzed for sperm count, sperm motility, and the percentage of deformed sperm. A total of

\section{DID YOU KNOW:}

\section{Hypospadia}

THE FREQUENCY RATE FOR HYPOSPADIA HAS MORE THAN DOUBLED SINCE 1970. IN 1993, 1 OF EVERY 125 BOYS WAS AFFECTED. ${ }^{\text {xxvi }}$

\section{Sperm Count}

THE SPERM COUNT FOR THE AVERAGE MALE IN 1938 WAS 113 MILLION/ML. THE SPERM COUNT FOR THE AVERAGE MALE IN 1990 WAS 66 MILLION/ML, A 50\% DECLINE IN APPROXIMATELY 50 YEARS. ${ }^{\text {Xxviii }}$

\section{Sex Ratio}

THERE IS CURRENTLY A DECREASE OF 1 MALE BIRTH IN 1000 LIVE BIRTHS WHICH RESULTS IN A LOSS OF APPROXIMATELY 38,000 MALE BABIES IN 20 YEARS IN THE UNITED STATES. ${ }^{x x i x}$

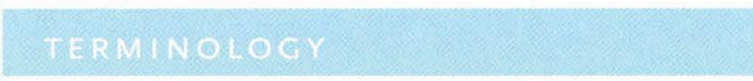

\section{Hypospadia}

\begin{abstract}
A MALE BIRTH DEFECT IN WHICH THE OPENING OF THE URETHRA, USUALLY AT THE TIP OF THE PENIS, IS ABNORMALLY PLACED (OPENING SOMEWHERE ALONG THE SHAFT).
\end{abstract}

\section{Anogenital Distance}

THE DISTANCE OF THE PERINEUM (BETWEEN THE ANUS AND THE BASE OF THE PENIS FOR A MALE). THE AGD IS TWICE AS LONG IN MALES THAN FEMALES, SO THE MEASURE IS USED IN NEONATAL HUMANS TO CORRELATE FEMINIZATION (REPRODUCTIVE ABNORMALITIES) TO CONTAMINANT BLOOD OR UREA LEVELS. 
eight different phthalate metabolites were found in the urine samples. Men with high levels of the dibutyl phthalate metabolite were more than twice as likely to have low sperm motility than men with low levels of the metabolite. High levels of other phthalates were also linked with reduced sperm count and a higher percentage of deformed sperm. This study reveals the connections between phthalate levels in the American male population and impaired sperm quality and quantity. $x x x$

Similarly, studies have indicated worldwide declining sperm counts. A review of 6I studies published in 1992 discovered that the average male sperm count dropped from II3 million/ml in I938 to 66 million/ml in I990. xxxi A change this drastic in such a short time period cannot be solely genetically determined, so the answer most likely lies in environmental influences. There are numerous theories concerning the sperm count decline, one being the involvement of EDCs, especially since women of childbearing age are one of the groups with the highest exposure levels. xxxii

Exposure to endocrine disruptors affects wildlife as well. In an isolated lake ecosystem, fish populations exposed to the synthetic estrogen found in birth control pills collapsed due to feminization of males. Arrested testicular development and subsequent reduced fertilization success led to a near extinction of the fathead minnow in the lake. Therefore, low-level, consistent exposure has the ecological risk of disrupting the sustainability of wild populations. xxxiii

\section{IMPORTANCE}

The scope of the damage endocrine disrupting chemicals have caused and their potential for damage in the future necessitates awareness. Instead of accepting the potential danger, or condemning all chemicals as dangerous it is instead important to regulate exposure in order to reduce the effects. There are over 80,000 chemicals registered with the U.S. Environmental Protection Agency, approximately 3,000 labeled as high production volume (accounting for 99 percent of the total volume), with at least one million pounds produced or imported in the U.S.xxxiv of these 3,000 high production volume chemicals, 43 percent have no basic toxicity testing data available to the public and only 7 percent have the full basic testing information. ${ }^{x x x y}$ Each chemical has six basic tests specified and with a cost of $\$ 205,000$ per chemical, it would cost the chemical industry approximately $\$ 427$ million to complete the basic testing of the high production volume chemicals. Though this is a high expense, an argument that the chemical industry pleads frequently, in reality, it is only 0.2 percent of the annual sales of the top hundred chemical industries.xxxvi Aside from these basic tests, no chemical has been adequately tested for endocrine disruption. Action will require policy changes to ensure the sustainability of life on earth.

Most Americans assume that chemicals used in products are safe; however, unlike the drug industry, the government has to prove that a chemical is harmful, rather than requiring the manufacturers to prove that it is safe before use.xxxvii This protocol, along with unenforced testing, lends to an unregulated chemical industry and the use of

\section{DID YOU KNOW?}

\section{Teflon, used as a non-stick coating for cookware, can emit toxic particles.}

IN 2-5 MIN, TEFLON-COATED COOKWARE CAN REACH TEMPERATURES AT WHICH THE COATING BREAKS AND EMITS TOXIC PARTICLES AND GASES LINKED TO HUNDREDS (MAYBE THOUSANDS) OF PET BIRD DEATHS AND AN UNKNOWN NUMBER OF HUMAN ILLNESSES EACH YEAR. xxxviii 
inadequately tested chemicals in consumer products. Increased testing prior to sale will require the development of an appropriate procedure because current testing for endocrine-disrupting abilities is convoluted, time-consuming, and varies between testers. A commitment by both the government and the chemical industry to safeguard the health of humanity is absolutely necessary. Recently, the Lowell Center for Sustainable Production and the Toward Tomorrow Initiative released "A Common Agenda for Health and the Environment," in which they "seek to help shift the debate about links between environment and health from a focus on which materials and substances cause which problems, to a discussion about what kind of world we want to live in and how we get there."xxxix Reflecting these ideals is the development of "green chemistry," which reduces waste, uses materials from sustainable sources, and tries to design chemicals that are less hazardous (in the short and long term) to human health. now common knowledge that BPA is found in plastic baby bottles. However, in the United States there is no national law regulating BPA in the bottles that feed the youngest, most susceptible citizens. Instead, elimination of BPA is determined on a state-by-state level. California has passed Senate Bill 578, that "requires manufacturers of High Production Volume chemicals to provide to the state information relating to whether a chemical causes or has the potential to cause cancer, reproductive harm, neurological damage, respiratory harm, endocrine disruption or developmental harm."xlii Also, Connecticut has banned BPA from infant formula and baby food cans and jars. xliii On the other hand, Massachusetts public health officials have only issued a warning to mothers to avoid baby products containing BPA. No official regulations have been passed. ${ }^{\text {liv }}$ Startlingly, a recent study performed by Health Canada reported that "BPA-free" baby bottles were in reality still leaching BPA, which further stresses the need for adequate

\title{
DID YOU KNOW?
}

\section{The FDA does not regulate what goes into cosmetics.}

\author{
61\% OF 33 BRAND-NAME LIPSTICKS TESTED BY THE CAMPAIGN FOR SAFE COSMETICS CONTAINED \\ DETECTABLE LEVELS OF LEAD. ${ }^{x l}$
}

ENVIRONMENTAL WORKING GROUP MEASURED 16 CHEMICALS FROM 4 CHEMICAL FAMILIES (PHTHALATES, TRICLOSAN, PARABENS, AND MUSKS) IN THE BLOOD AND URINE SAMPLES OF 20 TEEN GIRLS OF AGES 14 TO 19. $x$ li

Furthermore, development and implementation of policy and regulations to remove demonstrated endocrine disruptors is paramount. In the summer of 2008 , public awareness regarding BPA in Nalgene water bottles jumped, and subsequently, BPA was removed from these products. However, removal of endocrine disruptors in products is currently up to the companies and consumer pressure, rather than any regulatory enforcement. For example, it is testing and transparency within the chemical industry. ${ }^{x l v}$ Of course, obstacles still exist due to the number of products to regulate and incomplete ingredient lists due to "trade secrets." Yet, through research, we can become informed and consequently, can act.

\section{PROTECTING YOURSELF}

One of the most troubling aspects of EDCs is their ubiquity. 
From humans to animals, in the city or the Arctic, they are

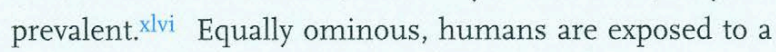
mixture of these chemicals constantly, not just one at a time or in a single dose. Exposure comes from the air we breathe, the grass we walk on, the foods we eat, and the products we apply to our skin. Studies looking at the way some of these chemicals work together show that they can enhance effects in a dose-additive or synergistic way. xlvii, xlviii For example, 35 percent of frog tadpoles exposed to a mixture of nine pesticides died due to a bacterial infection, compared to 4 percent fatality when exposed to a single pesticide. In addition, 70 percent of the mixture-exposed tadpoles that survived developed infections, seen in none of the controls or tadpoles exposed to one pesticide. ${ }^{x l i x}$ Also, EDCs do not share structural motifs, which makes their modes of action unpredictable. Since one chemical can act in numerous ways on multiple systems, our future in relation to these synthetic chemicals is entirely uncertain.

Currently, protection from endocrine disruptors means avoiding their sources. For example, plastics with numbers 3,6 , and 7 contain chemicals that are known to be EDCs. Plastic labeled "\#7" is frequently polycarbonate plastic, and through normal use, the plastic can suffer wear and tear, causing the BPA to leach out into liquids or food. Simply switching to a non-polycarbonate drinking water bottle can rapidly decrease the levels of BPA in blood and urine, shown by a study with 77 participants in which urine levels of BPA increased by 69 percent after using a polycarbonate water bottle compared to one week drinking cold beverages from a stainless steel water bottle instead. ${ }^{1}$ Microwaving in plastic is also dangerous as extreme heat causes plastic to lose its integrity, which results in chemical leaching.

Personal care products are another source of exposure, and reading labels can aid in reducing risk. Avoiding phthalates, parabens, and fragrances, and using the Skin Deep cosmetics database is the best way to secure products with minimal or low risks. Plus, exposures in a parent's body can show up in unborn children. Adopting precautionary principles will help decrease exposure to chemicals that are assumed to be safe, but may be labeled otherwise in 30 years. An unknown chemical on a label with unknown effects and little background information available should be avoided. It is not insured that companies are properly testing and monitoring the publically distributed chemicals. Dust-free houses are also safer as chemicals can reside in dust and can be maintained for a long time, accumulating and sensitizing the body. Phthalates found in dust samples have been linked to an increased incidence of allergic reactions in children, like asthma and eczema. ${ }^{\text {li }}$

Protection from EDCs is critical, but living in the chemicalladen twenty-first century makes completely avoiding EDCs impossible. Therefore, removing endocrine disruptors from our products, food, and air depends on advocating for change. Endocrine disruptors should not be in shampoos, furniture, and fruits. Because current testing methods and safety standards are not up to date and chemical companies lobby government regulatory departments, a consumer response is necessary. Fortunately, public knowledge about endocrine disruptors is increasing. The nail polish line OPI advertises being phthalate-free, the line Yes To Carrots provides paraben-free toiletries, and phthalates were outlawed from children's plastic toys in February 2009. .ii $^{\text {. }}$

\section{PROTECTING YOUR FUTURE}

As previously mentioned, a child developing in the womb is extremely susceptible to environmental influences. A single fertilized cell developing into an organism made up of trillions of cells is a staggering process aided by immensely complex signaling. In the third week after conception, the fetus is forming the origins of the brain, spinal cord, heart, and other organs. Cells must communicate instructions with one another on where to go, what to become, when to divide, and when to die. All of this depends upon relayed messages, many of them chemical. If endocrine disruptors become another component in a child's gestation period, the consequences can be monumental. It is known that drinking alcohol or smoking while pregnant 
poses major threats to the normal development (physically, mentally, and behaviorally) of a child, and endocrine disruptors can be just as dangerous. Effects can show themselves directly at birth, with genital abnormalities or immune deficiencies. Cognitive abnormalities or allergies may become apparent later, and results may even only show up in adulthood, with cancers, obesity, diabetes, and infertility problems.

Alarmingly, the parent and developing fetus are not solely affected by exposure. Endocrine disruptors also influence the fetus' germline cells. Germ cells eventually develop into the eggs or sperm cells of a child. Therefore, an exposed mother can inadvertently risk the normal development of her grandchildren as well. Studies have shown that endocrine disruptors can interfere with genetic imprinting in rats. Imprinting of DNA is a structural modification that can either allow or inhibit gene expression and can be passed down through the germ cells. Future generations can still exhibit effects due to the exposure of great-grandparents. liii These changes in the structure of DNA itself can lead to adult-onset disease, such as tumors, kidney dysfunction, and other problems like immune abnormalities and premature aging. ${ }^{\text {liv }}$

In addition to the potential for EDCs to cause permanent changes in the developing fetus and its germline, some EDCs are passed directly to the baby as "hand-me-down poisons." Many synthetic chemicals are lipid soluble and can accumulate in fat indefinitely. One such transfer can occur with breast milk. Endocrine disruptors are stored within the fatty tissue of the breast and then excreted through breastfeeding. BPA has been measured in the range of $0.2-5.0 \mathrm{ng} / \mathrm{ml}$ of breast milk, which underlines that exposure can come from many different sources. ${ }^{\text {lv }}$ Whether it is the pregnant mother's products, or her children's toys, awareness of these dangerous chemicals and how they play an integral part in our daily lives is crucial.

\section{CONCLUSION}

Research regarding endocrine disrupting chemicals is not just for scientists. It is not knowledge just for doctors, or lawyers, or moms, or even only humans. The changes that we are seeing in reproductive organs, in animal behavior, and in the rises of allergies and obesity are systems-level problems that need to be addressed in a transdisciplinary way. Endocrine disrupting chemicals are not the sole cause of any of these problems, but they undoubtedly contribute. It is important to remember that humans are both biological and cultural organisms embedded in social and ecological systems. Ivi EDCs, which put human reproductive success at risk, affect us both as a biological species and the way we will have to respond socially. Thinking about humans as agents acting within socio-ecological systems rather than external drivers will lead to more global, longlasting solutions. lvii 'This crisis begins at a personal, intimate level in regards to one's own body and extends to a global crisis of the human race and life on earth altogether. Recognizing the potential for harm and supporting research concerning the long-term effects of endocrine disruptors will lead to awareness, recognition, and political action in order to protect ourselves and future generations.

\section{ENDNOTES}

i. Norris (2006)

ii. McLachlan (200I)

iii. McLachlan (200I)

iv. ICIS (2008)

v. Rubin, et al. (2006)

vi. Masuno, et al. (2002)

vii. Calafat, et al. (2005)

viii. Rothman, et al. (I997)

ix. Lang, et al. (2008)

x. Hunt, et al. (2003)

xi. Durando, et al (2007)

xii. Jemal, et al. (2005)

xiii. Wetherill, et al. (2006)

xiv. Feldman (200I)

xv. Rubin, et al. (2006)

xvi. Howdeshell, et al. (1999)

xvii. Collaborative on Health and the Environment (2009)

xviii. Harley (2009)

xix. Collaborative on Health and the Environment (2009)

xx. Narita, et al. (2007)

xxi. National Center for Health Statistics, Centers for Disease

Control and Prevention (200I)

xxii. Sicherer, et al. (2003)

xxiii. Weisglas-Kuperus, et al. (2000) 
xxiv. Wozniak, et al. (2005)

xxv. Alonso-Magdalena, et al. (2006)

xxvi. Gray, et al. (2006)

xxvii. Paulozzi, et al (I997)

xxviii. Carlsen, et al. (1992)

xxix. Davis, et al. (1998)

xxx. Duty, et al. (2003)

xxxi. Colborn, et al. (1997)

xxxii. Our Stolen Future Online (2009)

xxxiii. Kidd, et al. (2007)

xxxiv. Breast Cancer Fund

xxxv. U.S. Environmental Protection Agency (2007)

xxxvi. Ibid.

xxxvii. Breast Cancer Fund

xxxviii. Houlihan, et al. (2003)

xxxix. Toward Tomorrow (2009)

xl. The Campaign for Safe Cosmetics (2007)

xli. Sutton, R. (2008)

xlii. Breast Cancer Fund

xliii. Daley, B. (2009)

xliv. Ibid.

xlv. Schmidt, S. (2009)

xlvi. Colborn, et al. (I997)

xlvii. Howdeshell, et al. $(2007$

xlviii. Hauser, et al. (2005)

xlix. Hayes, et al. (2006)

1. Carwile, et al. (2009)

li. Bornehag, et al. (2004)

lii. News Inferno (2008)

liii. Chang, et al. (2006)

liv. Anway, et al. (2006)

lv. Sun, et al. (2004)

lvi. Research Initiatives Subcommittee of the LTER Planning Process Conference Committee and the Cyberinfrastructure Core Team (2007)

lvii. Ibid.

\section{REFERENCES}

Alonso-Magdalena, P., Morimoto S., Ripoll, C., Fuentes, E., \& Nadal, A. 2006. The Estrogenic Effect of Bisphenol A Disrupts Pancreatic,Cell Function In Vivo and Induces Insulin Resistance. Environmental Health Perspectives 114(I), I06-II2.

Anway, M. D., Leathers, C., \& Skinner, M. K. 2006. Endocrine disruptor vinclozolin induced epigenetic transgenerational adult-onset disease. Endocrinology, 147(12), 5515-5523.

Bornehag, C., Sundell, J., Weschler, C. J., Sigsgaard, T., Lundgren, B., Hasselgren, M., \& Hägerhed Engman, L. 2004. The association between asthma and allergic symptoms in chil dren and phthalates in house dust: a nested case-control study. Environmental Health Perspectives I12 (I4), I393-I397.
Breast Cancer Fund. Chemical Information Act FAQ. Retrieved from <http://www.breastcancerfund.org/site/c.kwKXLdPaE/ b.3129987/k.CD4I/Chemical_Information_Act_FAQ.htm>.

Calafat, A.M., Kuklenyik, Z., Reidy, J.A., Caudill, S.P., Ekong, J., $\&$ Needham, L.L. 2005. Urinary Concentrations of Bisphenol A and 4-Nonylphenol in a Human Reference Population. Environmental Health Perspectives (II3), 391-395.

Carlsen, E., Giwercman, A., Keiding, N., \& Skakkebaek, N. E. 1992. Evidence for decreasing quality of semen during past 50 years. BMJ: British Medical Journal, 305(6854), 609-613.

Carwile, J. L., Luu, H. T., Bassett, L. S., Driscoll, D. A., yuan, C. Chang, J. Y., Ye, X., Calafat, A. M., \& Michels, K. B. 2009. Polycarbonate Bottle Use and Urinary Bisphenol A Concentrations. Environmental Health Perspectives 117, 1368I372.

Chang, H., Anway, M. D., Rekow, S. S., \& Skinner, M. K. 2006. Transgenerational epigenetic imprinting of the male germline by endocrine disruptor exposure during gonadal sex determination. Endocrinology, 147 (I2), 5524-554I.

Colborn, T., Dumanoski, D. \& Myers, J.P. 1997. Our Stolen Future. New York: Plume.

Collaborative on Health and the Environment 2009, January. Girl, Disrupted.

Daley, B. 2009, August 4. State warns on bottles with BPA. The Boston Globe. Retrieved from <http://www.boston.com/ news/health/articles/2009/08/04/massachusetts_issues_warn ing_on_bpa>.

Davis, D. L., Gottlieb, M. G., \& Stampnitzky, J. R. I998. Reduced ratio of male to female births in several industrial countries: A sentinel health indicator? Journal of the American Medical Association 279(13), 1018-1023.

Durando, M., Kass L., Piva, I., Sonnenschein, C., Soto, A.M., Luque, E. H., \& Munoz-de-Toro, M. 2007. Prenatal Bisphenol A Exposure Induces Preneoplastic Lesions in the Mammary Gland in Wistar Rats. Environmental Health Perspectives 115(I), 80-86.

Duty, S. M., Silva, M. J., Barr, D. B., Brock, J. W., Ryan, L., Chen, Z., et al. 2003. Phthalate exposure and human semen parameters. Epidemiology, 14(3), 269-277.

Feldman, B. J., \& Feldman, D. 20or. The development of androgen-independent prostate cancer. Nature Reviews Cancer $1,34-45$.

Gray Jr., L. E., Wilson, V. S., Stoker, T., Lambright, C., Furr, J., 
Noriega, N., Howdeshell, K., Ankley, G. T., \& Guillette, L. 2006. Adverse effects of environmental antiandrogens and androgens on reproductive development in mammals. International Journal of Andrology 29(I), 96-104. Published online 7 Feb 2006.

Harley, K. 2009, May 26. Girls are entering puberty earlier than ever. Environmental Health News. Retrieved from http://www.environmentalhealthnews.org/ehs/newscience/girl s-are-entering-puberty-earlier-than-ever.

Hauser, R., Williams, P., Altshul, L., \& Calafat, A. M. 2005. Evidence of interaction between polychlorinated biphenyls and phthalates in relation to human sperm motility. Enivronmental Health Perspectives 113(4), 425-430.

Hayes, T. B., Case, P., Chui, S., Chung, D., Haefele, C., Haston, K., Lee, M., Mai, V. P., Marjuoa, Y., Parker, J., \& Tsui, M. (2006). Pesticide mixtures, endocrine disruption, and amphibian declines: Are we underestimating the impact?

Environmental Health Perspectives, in press.

Houlihan J., Thayer, K., \& Klein, J. 2003, May. EWG finds heated Teflon pans can turn toxic faster than DuPont claims. Environmental Working Group. Retrieved from http://www.ewg.org/reports/toxicteflon.

Houlihan, J. \& Lunder S. 2007, August. Toxic Plastics Chemical in Infant Formula. Environmental Working Group. Retrieved from http://www.ewg.org/reports/bpaformula. (table modified)

Howdeshell, K. L., Furr, J., Lambright, C. R., Rider, C. V., Wilson, V. S., \& Gray, L. E.,Jr. 2007. Cumulative effects of dibutyl phthalate and diethylhexyl phthalate on male rat reproductive tract development: Altered fetal steroid hormones and genes. Toxicological Sciences, 99(I), 190-202.

Howdeshell, K. L., Hotchkiss, A. K., Thayer, K. A., Vandenbergh, J. G., \& vom Saal, F. S. I999. Environmental toxins: Exposure to bisphenol A advances puberty. Nature 401, $763-764$

Hunt, P. A., Koehler, K. E., Susiarjo, M., Hodges, C. A., Ilagan, A., Voigt, R. C., et al. 2003. Bisphenol A exposure causes meiotic aneuploidy in the female mouse. Current Biology, 13(7), 546-553.

ICIS (2008, December). Bisphenol A (BPA) Uses and Market Data. Retrieved from http://www.icis.com/v2/ chemicals/9075165/bisphenol-a/uses.html.

Jemal, A., Murray, T., Ward, E., Samuels, A., Tiwari, R. C., Ghafoor, A., et al. 2005. Cancer statistics, 2005. CA: A Cancer Journal for Clinicians, 55(I), I0-30.
Kidd, K.A., Blanchfield, P.J., Mills, K.H., Palace, V.P., Evans, R.E., Lazorchak, J.M., \& Flick, R.W. 2007 . Collapse of a fish population after exposure to a synthetic estrogen. PNAS, $104(2 \mathrm{I}), 8897-890 \mathrm{I}$.

Lang, I. A., Galloway, T. S., Scarlett, A., Henley, W. E., Depledge, M., Wallace, R. B., et al, 2008. Association of urinary bisphenol A concentration with medical disorders and laboratory abnormalities in adults. JAMA: The Journal of the American Medical Association, 300(II), I303-I310.

Masuno, H., Kidani, T., Sekiya, K., Sakayama, K., Shiosaka, T., Yamamoto, H., et al. 2002. Bisphenol A in combination with insulin can accelerate the conversion of 3 T3-LI fibroblasts to adipocytes. Journal of Lipid Research, 43(5), 676-684.

McLachlan, J. A. 200I. Environmental signaling: What embryos and evolution teach us about endocrine disrupting chemicals. Endocrine Reviews, 22(3), 3I9-34I.

Narita, S., Goldblum, R. M., Watson, C. S., Brooks, E. G., Estes, D. M., Curran, E.M., \& Midoro-Horiuti, T. 2007.

Environmental Estrogens Induce Mast Cell Degranulation and Enhance IgE-Mediated Release of Allergic Mediators. Environmental Health Perspectives 115(I), 48-52.

National Center for Health Statistics, Centers for Disease Control and Prevention 200I. New Asthma Estimates: Tracking Prevalence, Health Care and Mortality. Retrieved from $h t t p: / / w w w . a a f a . o r g /$ display.cfm?id= $8 \&$ sub $=42$.

News Inferno 2008, October 23. Despite Pending Ban, Toys Containing Phthalates Still On Shelves. Retrieved from http://www.newsinferno.com/archives/4068.

Norris, D. O. 2006. Endocrine disruption: biological bases for health effects in wildlife and humans. New York: Oxford University Press, p. 34

Our Stolen Future Online 2009, April I3. The science of sperm count declines. Retrieved from

http://www.ourstolenfuture.org/NewScience/reproduction/spe $\mathrm{rm} /$ sperm.htm.

Paulozzi, L. J., Erickson, J. D., \& Jackson, R. J. 1997.

Hypospadias trends in two US surveillance systems. Pediatrics, $100(5), 831-834$.

Research Initiatives Subcommittee of the LTER Planning Process Conference Committee and the Cyberinfrastructure Core Team 2007. Integrative Science for Society and Environment: A Strategic Research Initiative. Retrieved from http://www.lternet.edu/decadalplan.

Rothman, N., Cantor, K. P., Blair, A., Bush, D., Brock, J.W., 
Helzlsouer, K., Zahm, S.H., Needham, L.L., Pearson, G.R., Hoover, R.N., Comstock, G.W., \& Strickland, P.T. 1997. A nested case-control study of non-Hodgkin lymphoma and serum organochlorine residues. The Lancet 350 (July 26), 240244 .

Rubin, B. S., Lenkowski, J. R., Schaeberle, C. M., Vandenberg, L. N., Ronsheim, P. M., \& Soto, A. M. 2006 . Evidence of altered brain sexual differentiation in mice exposed perinatally to low, environmentally relevant levels of bisphenol A. Endocrinology, $147(8), 368 \mathrm{I}-369 \mathrm{I}$

Schmidt, S. 2009 , August I. 'BPA-free' baby bottle contains toxic chemical: Health Canada. Retrieved from

http://www.canada.com/health/free+baby+bottle+contains+tox ic+chemical+Health+Canada/I88IG28/story.html.

Sicherer, S. H., Muñoz-Furlong, A., \& Sampson, H.A. 2003. Prevalence of peanut and tree nut allergy in the United States determined by means of a random digit dial telephone survey: A 5-year follow-up study. The Journal of Allergy and Clinical Immunology, 112(6), 1203-1207.

Solomon, G. M., \& Schettler, T. 2000. Environment and health: 6. endocrine disruption and potential human health implications. Canadian Medical Association Journal, 163(II), I $47 \mathrm{I}-1476$.

Sun, Y., Irie, M., Kishikawa, N., Wada, M., Kuroda, N., Nakashima, K. 2004. Determination of bisphenol A in human breast milk by HPLC with column-switching and fluorescence detection. Biomedical Chromatography 18(8), 50I-507.

Sutton, R. 2008, September. Teen Girls' Body Burden of Hormone-Altering Cosmetics Chemicals: Adolescent exposures to cosmetic chemicals of concern. Environmental Working Group. Retrieved from http://www.ewg.org/ reports/teens.

The Campaign for Safe Cosmetics 2007, October. A Poison Kiss: The Problem of Lead in Lipstick. Retrieved from www.safecosmetics.org.

Toward Tomorrow 2009. About the Initiative. Retrieved from http://www.towardtomorrow.org/about.php.

U.S. Environmental Protection Agency 2007, November 28. HPV Chemical Hazard Data Availability Study. Retrieved from http://www.epa.gov/HPV/pubs/general/hazchem.htm.

Vreugdenhil, H. J. I., Slijper, F. M. E., Mulder, P. G. H., \& Weisglas-Kuperus, N. 2002. Effects of Perinatal Exposure to PCBs and Dioxins on Play Behavior in Dutch Children at School Age. Environmental Health Perspectives 110, A593-A598.

Weisglas-Kuperus, N, Patandin, S., Berbers, G. A. M., Sas, T. C.
J., Mulder, P. G. H., Sauer, P. J. J., \& Hooijkaas, H. 2000. Immunologic Effects of Background Exposure to Polychlorinated Biphenyls and Dioxins in Dutch Preschool Children. Environmental Health Perspectives 108, 1203-1207.

Wetherill, Y. B., Hess-Wilson, J. K., Comstock, C. E. S., Shah, S. A., Buncher, C. R., Sallans, L., et al. 2006. Bisphenol A facilitates bypass of androgen ablation therapy in prostate cancer. Molecular Cancer Therapeutics, 5(12), 3181-3190.

Wozniak, A. L., Bulayeva, N. N., \& Watson, C. S. 2005. Xenoestrogens at Picomolar to Nanomolar concentrations trigger membrane estrogen receptor-alpha-mediated calcium fluxes and prolactin release in $\mathrm{GH}_{3} / \mathrm{B} 6$ pituitary tumor cells. Environmental Health Perspectives 113(4), 431-438. 